\title{
THE ENCHANTMENT OF TIKTOK AS GEN Z CREATIVITY PLACE IN SMA NEGERI 2 SURABAYA'S BATIK MOTIFS ONLINE EXHIBITION
}

\author{
Condro Wiratmoko ${ }^{1}$, Muchammad Bayu Tejo Sampurno ${ }^{2 *}$ \\ ${ }^{1}$ SMA Negeri 2 Surabaya, Surabaya \\ ${ }^{2}$ Universitas Gadjah Mada, Yogyakarta \\ 1ondwier@gmail.com, *2muchammad.bayu.t@mail.ugm.ac.id / m.bayutejo@gmail.com
}

\begin{abstract}
This study tries to identify the creative stages of SMA Negeri 2 Surabaya students in the creative process of making batik motifs. The creative process starts from manual and digital design, exploring features and how they manage TikTok content as a form of their online exhibition. Furthermore, this study also explores the technology of enchantment in the use of TikTok in an online batik motif exhibition conducted by students of SMA Negeri 2 Surabaya. This study used a qualitative method with a virtual ethnography approach through TikTok and participatory in SMA Negeri 2 Surabaya. The research is focused on April and May 2021, where the online exhibition is held. The results showed that using IoT and digital technology enabled students to transform from negative to positive on TikTok social media. TikTok is used as a space for students' creativity in doing critical thinking on segmentation, social media management, and how they display their work. In addition, the features in TikTok are natural necessities that make students more comfortable learning because they accommodate the needs of students as Gen Z, who do have intimacy with IoT and digital technology.
\end{abstract}

Keywords: enchantment of TikTok; Gen Z creativity place; SMA Negeri 2 Surabaya; batik motifs online exhibition

\begin{abstract}
Abstrak: Penelitian ini mencoba mengidentifikasi tahapan kreatif siswa SMA Negeri 2 Surabaya dalam proses kreatif pembuatan motif batik. Proses kreatif dimulai dari membuat desain manual dan digital, mengeksplorasi fitur dan bagaimana siswa mengelola konten TikTok sebagai bentuk pameran online. Selain itu, penelitian ini juga mengeksplorasi pesona teknologi melalui penggunaan TikTok dalam pameran motif batik online yang dilakukan oleh siswa SMA Negeri 2 Surabaya. Penelitian ini menggunakan metode kualitatif dengan pendekatan etnografi virtual melalui TikTok dan partisipatif di SMA Negeri 2 Surabaya. Penelitian ini difokuskan pada bulan April dan Mei 2021, waktu diadakannya pameran online. Hasil penelitian menunjukkan bahwa penggunaan IoT dan teknologi digital memungkinkan siswa untuk bertransformasi dari anggapan negatif menjadi positif dengan media sosial TikTok. TikTok digunakan sebagai wadah kreativitas siswa dalam melakukan pemikiran kritis tentang segmentasi, pengelolaan media sosial, dan bagaimana mereka menampilkan karyanya. Selain itu, fiturfitur TikTok merupakan kebutuhan alami yang membuat siswa lebih nyaman belajar karena mengakomodir kebutuhan siswa sebagai Generasi $Z$ yang memang memiliki keakraban dengan IoT dan teknologi digital.
\end{abstract}

Kata kunci: Pesona TikTok; tempat kreativitas Generasi Z; SMA Negeri 2 Surabaya; Pameran online motif batik

\section{INTRODUCTION}

The 21 st century also influences the implementation of the Internet of Things (IoT). IoT implementation has penetrated integration into several things: economy, marketing, social, politics, arts, culture, and education (Bown \& Ferguson, 2018). Incidental phenomena such as Covid-19, which was never expected to occur previously, also contributed to the massive implementation of IoT. Covid-19 seems to launch an IoT trajectory to dominate the world paradigm. The trajectory was initiated from at least three things, including (1) public pedagogy

Submitted: 27 Mei $2021 \quad$ Accepted: 28 Spetember 2021 Published: 30 September 2021 
about Covid-19 using social media, (2) online learning, and (3) online shopping (Marsudi et al., 2020; Sampurno et al., 2020).

The massiveness of the IoT cannot be denied. The generation fully supports the emergence of IoT in the 21 st century, who have intimacy with IoT, namely generation Z. Definitively, "generation Z" still lacks clarity. This means that there are still many definitions of generation Z, which is still an unpatented definition. However, in essence, generation $Z$ (or later called Gen Z) is referred to as the generation born after Generation Y (millennial), which includes those born in 1995 to 2010 (Nuroh \& Liansari, 2018). Furthermore, generally, those born are Gen Z, also known as iGeneration or internet generation or net generation (Canţer, 2012; King et al., 2019). This is because $\mathrm{Gen} \mathrm{Z}$ is always connected to cyberspace and can do everything by using existing technology (Colman, 2018).

The characteristics of Gen Z, which are close to IoT, need to be used as a mode of online shopping or a medium of existence and to interplay various kinds of needs with the field of education through learning. Interactive learning in the IoT era through social media has attracted academics, observers, and even scientists in the world of education (Goatley \& Johnston, 2013; Grossman, 2017). The implementation of IoT in learning with social media is a learning process that supports broad network interactions between students and the network community (netizens) (Versteijlen et al., 2017). By utilizing social media, it provides an opportunity for active discussion. In contrast to conventional learning, which only provides one-way communication, only teachers provide information to students (Castaño-Muñoz et al., 2014).

This research identifies the creative stages taken by SMA Negeri 2 Surabaya students in making digital batik to conducting exhibitions by utilizing the technology of enchantment from TikTok. Furthermore, this study also explains pedagogical collaboration from the creative stages and technology of enchantment as a medium that accommodates the wishes of Gen $\mathrm{Z}$ students who are sensitive to IoT. This is interesting because the context of learning after the Covid-19 pandemic will further explore digital technology. Therefore, it is hoped that this research will be able to become a reference in seeing opportunities for the use of educational technology and technology of enchantment from social media as one of the educational media.

\section{LITERATURE REVIEW}

Conventional complexity that occurs, for example, such as the arrangement of classrooms which usually follows the format of the teacher in front of the class chronologically providing material with a boomers teacher model (Yazdani \& Shahbazi, 2017), giving examples to students (Painter et al., 2012), and giving students opportunities to practicing alone with homework (Komalasari, 2010). This shows no significant problems in conventional learning, but there is a need for innovation in the learning model to provide active experiences to students. Therefore, interactive learning is an option for learning model solutions in the IoT era and in contemporary education that utilizes the digital world (Bown \& Ferguson, 2018; Knežević \& Kovačević, 2011; Li et al., 2020; Strycker, 2020).

One of the interactive learning with social media is to explore the technology of enchantment it has, like the learning of Cultural Arts subject at SMA Negeri 2 Surabaya, Surabaya, East Java, Indonesia. The Cultural Arts subject at SMA Negeri 2 Surabaya is a compulsory subject which in this pandemic was held for 45 minutes for 1 lesson hour every week. Cultural Arts subjects provide an understanding of the variety of Indonesian arts and culture, but more than that. This Cultural Arts subject also accommodates the needs of Gen Z students who are digital natives. The trick is to collaborate between learning and social media and the technology of enchantment in it. Efforts are related to data on social media usage, which continues to grow with more than two billion users worldwide, representing $28 \%$ of the entire population (Lim \& Wang, 2005). Students as a generation of digital natives spend about two hours a day using social media, and half of the users stated that it would be difficult to let go of social media in their daily lives (Patton \& 
Buffington, 2016; Prensky, 2001; Priyaadharshini et al., 2020). Therefore, it is essential to explore this potential if there is a relationship between social media addiction and the emotions that students describe when placed in an academic environment such as in the classroom.

\section{METHODS}

The qualitative approach used as the methodological basis for this research. The analytical research approach used is a virtual ethnographic method which is considered to allow researchers to comprehensively view the content of SMA N 2 Surabaya batik motifs online exhibition on TikTok. In addition, virtual ethnography allows researchers to select and take important points as needed research findings (Boellstorff et al., 2012; Hine, 2001). Furthermore, a limitation of this method relates to seeing the content from the point of view of the audience and observer, rather than from the point of view of the SMA N 2 Surabaya student as producer (Fabian, 2008). The virtual ethnography method is used as an investigation effort on the use of the internet which has meaning for the social life of society (Hine, 2001). At this level, TikTok as interactive media is understood as both IoT and technology culture itself and a digital culture artifact and allows researchers to see mediated interactions in the virtual as well as the physical realm (Hine, 2001). Moreover, the boundary between "virtual" and "real" cannot be considered as something that is taken for granted. TikTok as the context in this study can be understood as a digital culture artifact that forms or is formed by the IoT culture itself. This method allows researchers to engage with the object of study within a specified time span, even periodically, without having to immerse themselves in a long period of time, because the researcher also acts as a teacher of Cultural Arts subjects at SMA Negeri 2 Surabaya. This makes it easier for researchers to be in an active participatory position in collecting research data. This research focused on April and May, which are the opening months for batik motifs online exhibition events on TikTok. The research subjects were students of class XI SMA Negeri 2 Surabaya. After the data was collected, the analysis was carried out using an interactive model belonging to Miles and Huberman to obtain research findings related to technology of enchantment from an online exhibition on TikTok (2018).

\section{RESULT AND DISCUSSION}

During this pandemic, the Indonesian government, through the Ministry of Education and Culture, has provided free quota assistance to students and teachers ranging from Elementary Education to Higher Education. The government has also restricted several inaccessible network platforms through internet quota assistance that can be used, including TikTok. The hope is that the quota assistance can be maximally used in learning and not used to access platforms that harm the learning process, such as online games and social media.

It must be realized that today's tendency with technology, especially in the middle to the upper-class economy, is challenging to control from its negative aspects. The fact that the world of online games and social media is the trend of today's students (Ashton, 2009; Chan et al., 2019; Gomis-Porqueras \& Rodrigues-Neto, 2018; Kim et al., 2018; Szymański, 2019). The problem in online learning is the low level of effectiveness with unequal access among the middle to lowerclass economies. Dra. Ligawati, M.Pd. as the principal of SMA Negeri 2 Surabaya, revealed that during this pandemic, teachers expected to provide maximum material with various media and the duration of time, which is undoubtedly reduced from the duration of conventional learning (comments related to learning during the pandemic, April 2021). If each teacher only gives assignments, the fact is that it becomes a polemic for a bad psychological burden on students and parents. In line with Nadiem Makarim's statement as the Minister of Education through the Indonesian Ministry of Education and Culture's YouTube channel (Kemdikbud RI) regarding the Announcement of Learning Policy Adjustments during the Covid-19 Pandemic (Pengumuman Penyesuaian Kebijakan Pembelajaran di Masa Pandemi Covid-19), many obstacles faced by 
teachers in online learning and this is also a challenge for teachers (KEMDIKBUD RI, 2020). Nadiem also revealed that one of the impacts of online learning is the loss of student interest in learning or, in the term, loss of learning (KEMDIKBUD RI, 2020).

Chairman of the Surabaya Education Council Dr. Martadi, M.Sn., revealed that online learning is a moment for teachers to explore blended learning in the new normal future (interview on April 2021). The exciting thing is that many teachers born from the analog generation (digital immigrants) in the digital era are trying to become content creators in learning. The potential in the digital era is an abundant source of learning, and with easy access, this hope can be maximized to encourage digital media literacy in learning (Kosnik et al., 2016). Therefore, today's learning has the potential to enter the world of today's participants, one of which is maximizing social media in learning.

SMA Negeri 2 Surabaya as the one of the favorite schools in Surabaya, with students who mostly have digital devices in online learning such as laptops or smartphones. Through the Class XI class of Cultural Arts, currently organizing digital exhibitions through the social media platforms TikTok. The content in the exhibition displayed is a digital batik motif design with an innovative and creative concept that can be seen through the hashtag \#desainmotifbatiksmadabaya2021. The digital exhibition is output form the project-based learning. One large class containing 36 students is divided into small groups with 3-4 students in it. From this group, each individual makes a form of batik motif design from the group's inspiration source. Digital batik motif design is a technique of designing batik motifs by involving digital technology through design software tools installed on laptops, smartphones, or accessed online in the process. The initial process in this project is by researching the source of inspiration that wants to be transformed into a batik motif design which is then realized using a manual sketch using a pencil on drawing paper. Furthermore, the manual sketch is scanned or photographed for processing using design software and digitally reproduced through the tracing, coloring, and composition process. The final result of this process, students make a mock-up of the batik motif design on the mock-up material of white clothes or school uniforms (Figure 1).
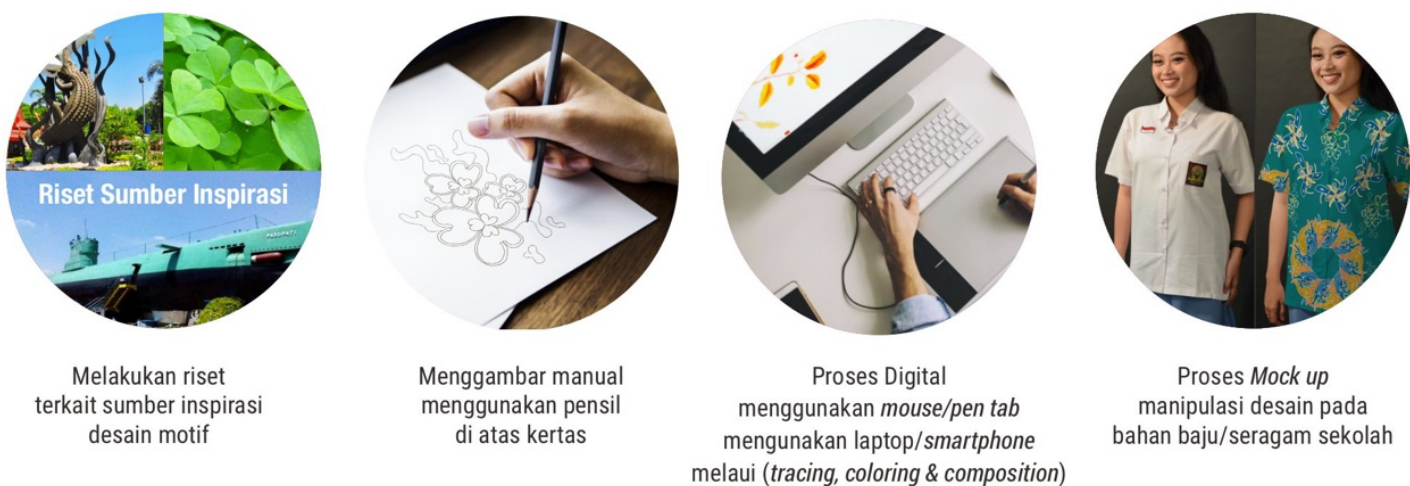

Figure 1. The process of making digital motifs batik

The detail of student's creative process in utilizing TikTok's enchantment technology includes the preparation stage, the incubation stage, the illumination stage, and the verification stage (Arnold \& Iversen, 2003; Botella et al., 2013; Johnston-Goodstar et al., 2014). The creativity stage explains that there is an early analysis phase of the problem at the preparation stage (Richardson, 2020). At this stage, students will collect as much information as possible to produce their work. At the incubation stage, students will find themselves distracted by the problems in their work while thinking subconsciously continues to solve the problems in their work. The next stage is illumination, which starts from the end of the incubation stage, where an idea or solution suddenly appears. The last stage is verification, where students must prove that the solutions 
obtained can work well and solve problems in their work. The four stages above are eventually developed into six stages into ideas or vision, documentation and reflection, sketches, form testing, provisional objects, and work publication (Botella et al., 2013). This is because in creating digital batik and exhibitions through TikTok's technology of enchantment, students formulate the stages of the creative process and map the factors that affect students in each stage of the creative process.

Students are directed to come up with ideas in the idea or vision stage after recalling their experiences and knowledge. The emergence of ideas or visions can be triggered by images, visions, or sounds, apart from students' experiences and knowledge. The second characteristic is the nature of the artistic vision that appears not personal but interpersonal, where students need 'input' from other significant personalities, in this case, teachers, peers, and netizen comments when posted on TikTok (Figure 2). Meanwhile, the third characteristic is the nature of the idea or vision, which is still broad, thematic, and does not yet have an idea of its visual form.

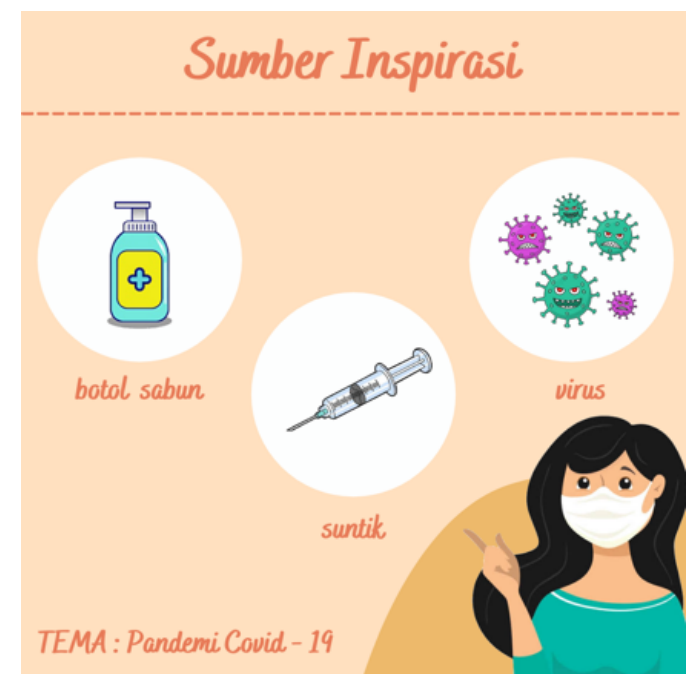

Figure 2. Covid-19 global pandemic as interpersonal student inspiration

Two factors influence student activity at this stage: the material world and social world factors (Agnoli et al., 2016; Botella et al., 2013; Sampurno, 2018). The social world in this stage is friends and family, while the material world is another object. In the context of digital batik and its use through TikTok's technology of enchantment, the social world refers to students' social activities in social media networks, especially when they are in an exhibition space in TikTok, in the hashtag feature. Meanwhile, other objects from the material world refer to objects that students interact with at the beginning of the creative process.

After going through the idea stage, students move to the documentation and reflection stages. The main characteristic of this second stage is the emergence of the need for information regarding the technology and materials required. At this stage, potential problems that can arise are deadlocked ideas and irregularities in creation where students cannot be forced to get inspired in a short time. However, with interpersonal support, students can carry out documentation and reflection influenced by the material world in which there are material sources. The material source refers to material in the form of visual objects with elements with specific attributes such as color, saturation, and composition.

The next stage is a sketch (Figure 3), where students do the first experiment in producing artwork. The work at this stage is not always a finished image that will be used. It can also be a draft or a design model. The draft in question can be a two-dimensional sketch. The material world that is influential in the first sketch stage is a new material that has not been explored, while the social world is influenced by collaborators, in this case, peers and input from the teacher. 
Therefore the material is in the form of decorative ornaments or motifs. New materials in the material world can refer to batik ornaments that can arise from the process of creation and modification.

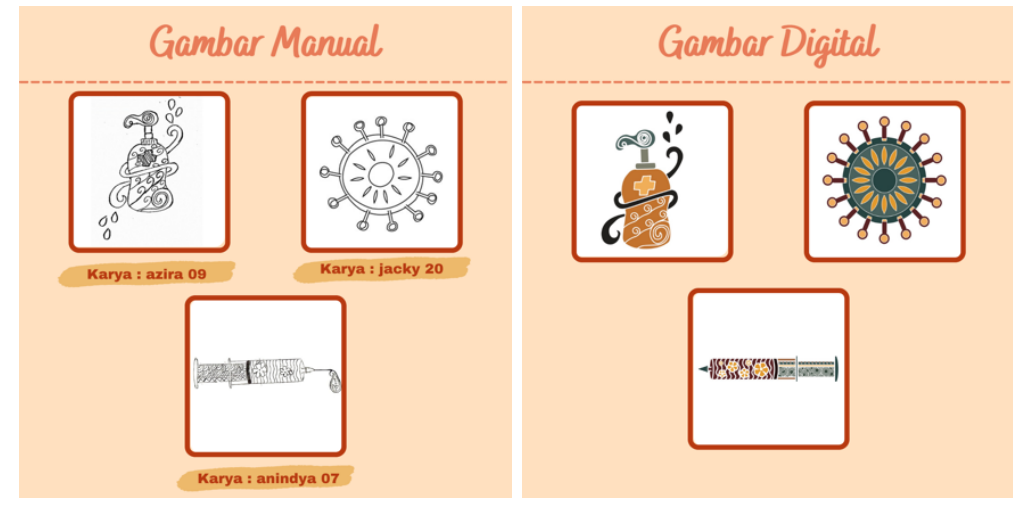

Figure 3. Manual sketch and digital sketch

After students make a sketch, continue with a discussion to see the model or image design applied to the mockup (Figure 4). This is to see whether the sketch can meet students' expectations and can be finalized. At this stage, there is an inner confrontation between the student and the sketch he is testing.
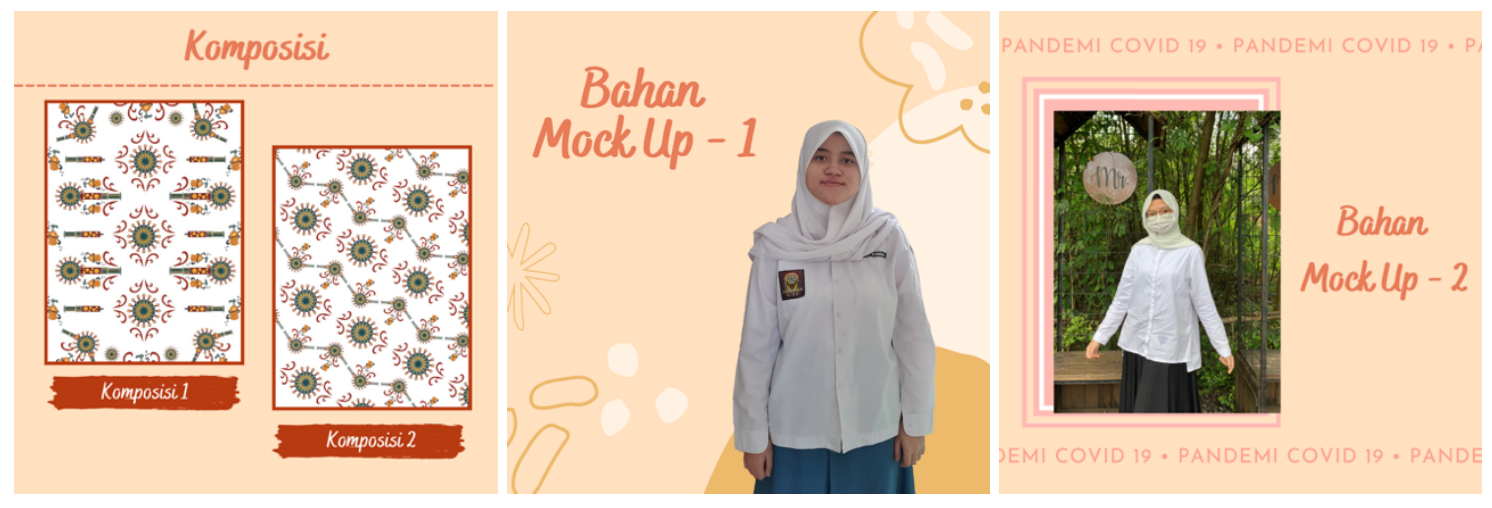

Figure 4. Batik motifs design applied on mockup

Next is the provisional object, which is commonly known as implementing the digital batik design in the mockup (Figure 5). The temporary work stage is a refinement of the form/idea testing stage. The characteristic of this stage is that there is a physical form of the idea that has been put on paper, is digitized, and its implementation in functional objects has been considered. Another characteristic is that this stage requires detailing, refining, and adjusting to the context. In the provisional object, there is an influence from the factors of the material world, namely technical matters. Students as generation $\mathrm{Z}$ as digital natives can easily understand and master the features in Adobe Photoshop software and how they are applied in TikTok as an exhibition space. 


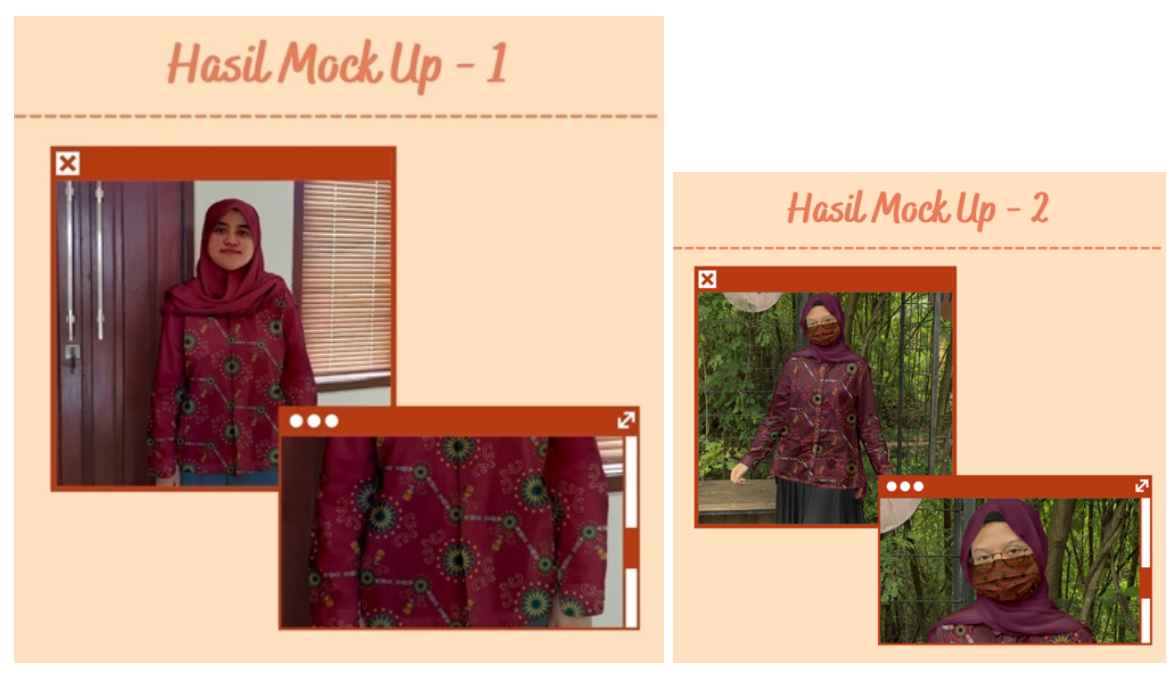

Figure 5. Implementing the digital batik design in the mockup

The stages of mastery of the material on the TikTok features bring out the technology of enchantment which is influenced by the level of complexity of students in editing the display of their batik design work to make it more attractive to netizens. The exhibition on TikTok, in collaboration with the technology of enchantment, is the estuary of all the previous stages. The exhibition at TikTok collaborates with the technology of enchantment, where the complexity lies in the complexity of linear processes and cyclic processes. The process finds a form that will eventually lead to a digital batik exhibition through TikTok. This makes the output of the creative process from art learning for generation $\mathrm{Z}$ students not only in the form of one work but also in several works originating from repeated stages of the creative process and with attractive packaging.

Azira, one of the students from class XI IPA 2, revealed that the exciting thing about the digital process is the mock-up process or a form of manipulation of digital batik motif designs on clothes by maximizing school uniforms and cameras from smartphones are owned for photography. From this process, he must become a model of clothes to be used as mock-up material or manipulation of batik motif designs. Azira, Jacky, and Anindya are proud of the pandemic batik motif designs they made and made as if they had been produced into clothes from the batik motif design process. They also revealed that through digitizing this batik motif design, it is easy to make designs quickly, and there are many variations.

From the results of his digitally made batik motif designs, the teacher revealed that it would be a shame if he was only judged by himself as a teacher. Therefore, he began to think that this work should be exhibited digitally through social media to get appreciation both through likes and comments. The teacher wants to maximize social media as a medium for exhibition, but with a different concept. Therefore he learns and tries to understand the world of social media for his students. From his observations, it turns out that every class of social media is displayed in interesting content management. Therefore, the teacher assigns a class exhibition assignment by managing the social media platform of each class according to the number of groups. Another thing from this exhibition that the teacher has in mind is scheduling the posting process for each class and defining specific and general hashtags in nature. The hashtag with the special status of the exhibition on social media is \#desainmotifbatiksmadabaya2021, while the general hashtag is \#batik \#motifbatik \#desainmotifbatik \#merdekabelajar (Figure 6). Setting the posting schedule aims to see the content management display of each class through unique hashtags that are intact and not random. 


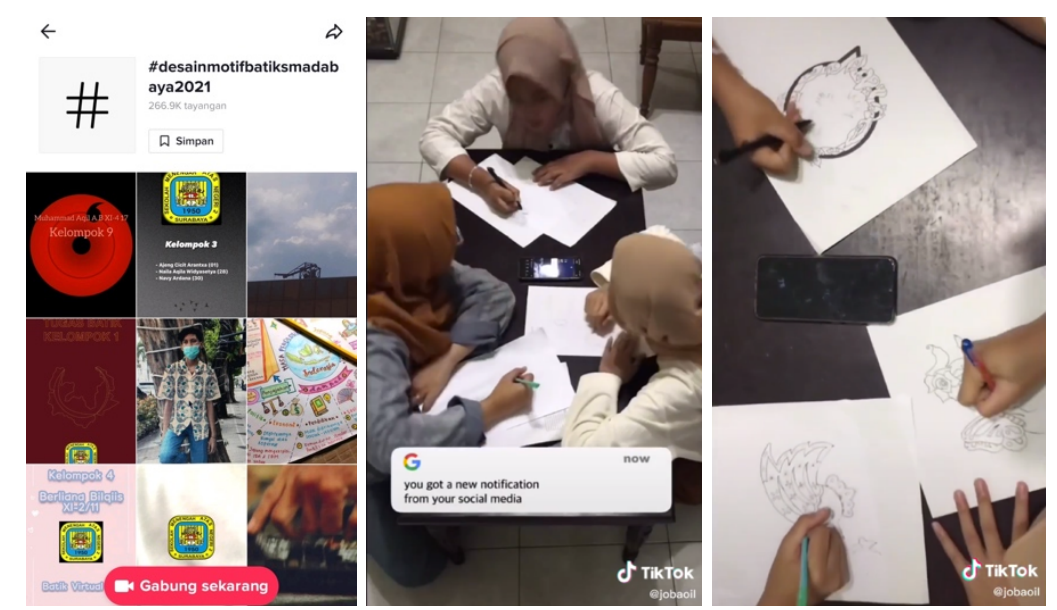

Figure 6. hashtag as exhibition and display room for students artwork

This exhibition takes place through the TikTok social media platform, with the demands of each individual to make a video of the design process of each individual. TikTok is currently a viral social media among the millennial generation, with millions of users in Indonesia. Using TikTok is the teacher's consideration that he hopes that students' work can be seen and appreciated by many TikTok users. In this exhibition, students are required to be able to maximize smartphones for the video editing process. The video contains sequences from the concept of the source of inspiration, the manufacturing process, and the final result of the digital batik motif design. Until the end of May 2021, the exhibition on TikTok, which can be seen through the hashtag \#designbatiksmadabaya2021, has been viewed more than 266,000 times, ten thousand likes, and thousands of comments from TikTok users.
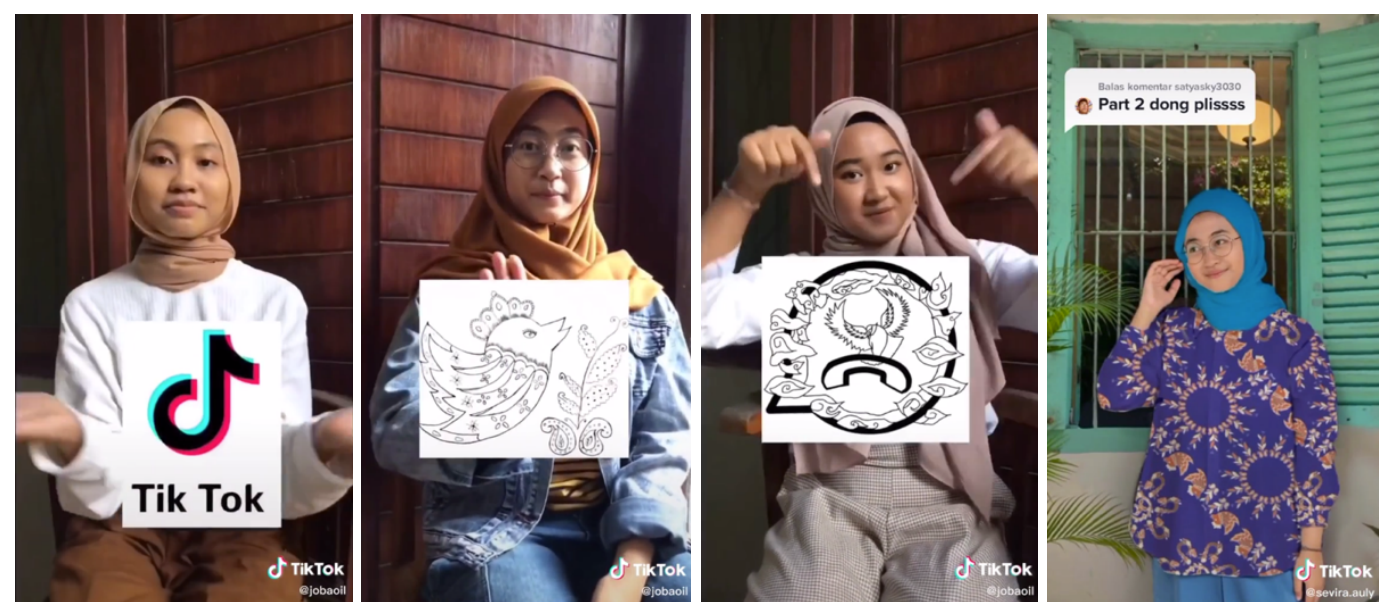

Figure 7. Exploration of creativity and online exhibition as technology enchantment of TikTok

The online exhibition on TikTok is inseparable from the technology of enchantment in the displays of student work. This is manifested by students through various creative work efforts, as previously stated. It can be said that SMA Negeri 2 Surabaya students display extra-daily (outsidedaily) forms and techniques (Gell, 2006; Simatupang, 2013), by collaborating with IoT. Exploration of technology in TikTok features carried out in online exhibitions is also an effort to realize the aesthetic expressions that SMA Negeri 2 Surabaya students strive for through the subject of Cultural Arts. The sensations that are generated lead netizens to be fascinated so that they enter a state where a force controls the awareness and direction of one's attention outside of themselves, such as netizens who are waiting for Part 2 of the video clips of the online exhibition 
(Figure 7) (Simatupang, 2013). This refers to Gell discussing aesthetic issues in art where it does not refer specifically to beauty but refers to the sensation he calls enchantment (Bettelheim, 1997; Gell, 2006). Gell also emphasized that the power of art objects stems from the technical processes they objectively embody: the technology of enchantment is founded on the enchantment of technology (Gell, 2006). The enchantment or technology is tehe power that technical processes have of casting a spell over us so that we see the real world in a enchented form. Art, as a separate kind of technical activity, only carries further, through a kind of involution, the enchantment which is immanent in all kinds of technical activity (Gell, 2006). The enchantment of technology built in the online exhibition on TikTok as an art aims to foster enchantment, while in terms of technique (technology) itself, one of which is the level of difficulty, is indeed charming. Furthermore, it is said that the enchanting technique has a kind of aura or effect that radiates and envelops objects and students of SMA Negeri 2 Surabaya as art actors. The enchantment that is displayed also raises the potential of public pedagogy through TikTok social media, with its origin in the form of creativity. Through the online exhibition on TikTok, netizens are invited to explore how the public or netizens can accept the "charm" of batik and technology exploration from Gen Z.

\section{CONCLUSION AND SUGGESTIONS}

TikTok, nowadays as a viral social media, contributes to public pedagogy through its technology of enchantment. This is supported by the creativity of SMA Negeri 2 Surabaya students as Gen Z who do have intimacy with IoT. At every stage of the creative process in making batik motifs so that they are exhibited online through TikTok, some aspects can increase creativity. Students have high potential in exploring technology. Collaboration between students, teachers, and netizens in their comments also increased students' knowledge and perspective. Using TikTok, the student learning space expands and ignores the boundaries of physical space that are usually an obstacle in conventional classrooms. From this technology of enchantment batik motifs exhibition on TikTok, students dan encourage they creativity in arts and culture through the digital world during this pandemic. In addition, we hope that this activity can become a reference for teachers with various fields of knowledge to explore the digital world, such as social media in online learning. The more learning content on social media, of course, the more knowledge that can be shared.

The technology of enchantment provides suggestions for future research that should be explored, namely on the psychological aspects of Gen Z students. Symptoms that arise from this study are the implications of transforming the adverse effects of social media addiction into a more positive form. First, the adverse effects of social media addiction can be reduced by emotional achievement and critical thinking. Based on the responses from exhibition visitors on TikTok, by carrying out creative exploration of TikTok's educational potential, students use social media to increase their creativity and self-confidence. Furthermore, ignoring other activities that are less productive with the use of social media opens the potential for the emergence of public pedagogy. In addition, the effects of addiction on students' explorations for online social media exhibitions enrich critical thinking. By exploring TikTok's features, students can identify choices when faced with problems, provide reasons for their opinions, and/or rank ideas according to their priorities. This is reflected in the exhibition content management carried out by students. They are neatly archiving, identifying social media segments, studying the appropriate upload time, choosing effects and songs used in their work displays. 


\section{REFERENCE}

Agnoli, S., Corazza, G. E., \& Runco, M. A. (2016). Estimating Creativity with a MultipleMeasurement Approach Within Scientific and Artistic Domains. Creativity Research Journal, 28(2), 171-176. https://doi.org/10.1080/10400419.2016.1162475

Arnold, D., \& Iversen, M. (2003). Art and Thought. Blackwell Pub.

Ashton, D. (2009). Thinking with games: Exploring digital gaming imaginaries and values in higher education. Journal of Media Practice, 10(1), 57-68. https://doi.org/10.1386/jmpr.10.1.57_1

Bettelheim, B. (1997). The Uses of Enchantment: The Meaning and Importance of Fairy Tales. Vintage.

Boellstorff, T., Nardi, B., Pearce, C., \& Taylor, T. L. (2012). Ethnography and Virtual Worlds: A Handbook of Method. Princeton University Press.

Botella, M., Glaveanu, V., Zenasni, F., Storme, M., Myszkowski, N., Wolff, M., \& Lubart, T. (2013). How artists create: Creative process and multivariate factors. Learning and Individual Differences, 26, 161-170. https://doi.org/10.1016/j.lindif.2013.02.008

Bown, O., \& Ferguson, S. (2018). Understanding media multiplicities. Entertainment Computing, 25(October 2017), 62-70. https://doi.org/10.1016/j.entcom.2017.11.001

Canţer, M. (2012). E-heutagogy for lifelong e-learning. Procedia Technology, 1, 129-131. https://doi.org/10.1016/j.protcy.2012.02.025

Castaño-Muñoz, J., Duart, J. M., \& Sancho-Vinuesa, T. (2014). The Internet in face-to-face higher education: Can interactive learning improve academic achievement? British Journal of Educational Technology, 45(1), 149-159. https://doi.org/10.1111/bjet.12007

Chan, C. S., Chan, Y. hang, \& Fong, T. H. A. (2019). Game-based e-learning for urban tourism education through an online scenario game. International Research in Geographical and Environmental Education, 2046. https://doi.org/10.1080/10382046.2019.1698834

Colman, A. (2018). Net.art and Net.pedagogy: Introducing Internet Art to the Digital Art Curriculum. Studies in Art Education, 46(Technology Issue), 61-73.

Fabian, J. (2008). Ethnography as Commentary: Writing form the Virtual Archive. Duke University Press. https://doi.org/10.1017/CBO9781107415324.004

Gell, A. (2006). Technology of Enchantment and Enchantment of Technology. In E. Hirsch (Ed.), The Art of Antrophology Essay and Diagrams. Athlone Press.

Goatley, V. J., \& Johnston, P. (2013). Innovation, Research, and Policy: Evolutions in Classroom Teaching. Language Arts, 91(Innovations), 94-104.

Gomis-Porqueras, P., \& Rodrigues-Neto, J. A. (2018). Teaching technologies, attendance, learning and the optimal level of access to online materials. Economic Modelling, 73(May 2017), 329-342. https://doi.org/10.1016/j.econmod.2018.04.009

Grossman, J. (2017). Adaptation in Visual Culture. In Adaptation in Visual Culture. Palgrave Macmillan. https://doi.org/10.1007/978-3-319-58580-2

Hine, C. (2001). Virtual Ethnography. Sage Publications. https://doi.org/10.4324/9781315797915-4

Johnston-Goodstar, K., Richards-Schuster, K., \& Sethi, J. K. (2014). Exploring Critical Youth Media Practice: Connections and Contributions for Social Work. Social Work (United States), 59(4), 339-346. https://doi.org/10.1093/sw/swu041

KEMDIKBUD RI. (2020). Pengumuman Penyesuaian Kebijakan Pembelajaran di Masa Pandemi Covid-19. https://www.youtube.com/watch?v=WdF5LOz10TM

Kim, S., Song, K., Lockee, B., \& Burton, J. (2018). Gamification in Learning and Education Enjoy Learning Like Gaming. Springer.

King, A., Prior, H., \& Waddington-Jones, C. (2019). Exploring teachers' and pupils' behaviour in online and face-to-face instrumental lessons. Music Education Research, 21(2), 197209. https://doi.org/10.1080/14613808.2019.1585791

Knežević, S., \& Kovačević, B. (2011). Interactive learning and students' competences in 
teaching literature. Metodički Obzori, 6(13), 83-92.

Komalasari, K. (2010). Pembelajaran Kontekstual: Konsep dan Aplikasi. Refika Aditama.

Kosnik, C., White, S., Beck, C., Marshall, B., Lin Goodwin, A., \& Murray, J. (Eds.). (2016). Building Bridges: Rethinking Literacy Teacher Education in a Digital Era. Sense Publishers. https://doi.org/10.1007/978-94-6300-491-6

Li, H., Kim, M. K., \& Xiong, Y. (2020). Individual Learning Vs. Interactive Learning: A Cognitive Diagnostic Analysis of MOOC Students' Learning Behaviors. American Journal of Distance Education, 34(2), 121-136. https://doi.org/10.1080/08923647.2019.1697027

Lim, K. Y. T., \& Wang, J. Y. Z. (2005). Collaborative handheld gaming in education. Educational Media International, 42(4), 351-359. https://doi.org/10.1080/09523980500237765

Marsudi, M., Sampurno, M. B. T., Wiratmoko, C., \& Ratyaningrum, F. (2020). Kontribusi Desain Komunikasi Visual dalam Anti-Hoax System saat Pandemi Covid-19 di Indonesia. SALAM: Jurnal Sosial Dan Budaya Syar-i; Vol 7, No 10 (2020): Special Issue Coronavirus Covid-19DO - 10.15408/Sjsbs.V7i10.15844. http://journal.uinjkt.ac.id/index.php/salam/article/view/15844

Miles, M. B., Huberman, A. M., \& Saldana, J. (2018). Qualitative Data Analysis: A Methods Sourcebook (4th ed.). Sage Publications.

Nuroh, E. Z., \& Liansari, V. (2018). Digital Age Literacy in Elementary School. 1st International Conference on Intellectuals' Global Responsibility, 125(ASSEHR), 119123. https://doi.org/10.2991/icigr-17.2018.29

Painter, C., Martin, J. R., \& Unsworth, L. (2012). Reading Visual Narratives: Image Analysis in Children's Picture Books. Equinox. https://doi.org/10.1080/10350330.2014.950010

Patton, R. M., \& Buffington, M. L. (2016). Keeping up with our students: The evolution of technology and standards in art education. Arts Education Policy Review, 117(3), 1-9. https://doi.org/10.1080/10632913.2014.944961

Prensky, M. (2001). Digital Natives, Digital Immigrants. On the Horizon, 9(5).

Priyaadharshini, M., NathaMayil, N., Dakshina, R., Sandhya, S., \& Bettina Shirley, R. (2020). Learning analytics: Game-based Learning for Programming Course in Higher Education. Procedia Computer Science, 172(2019), 468-472. https://doi.org/10.1016/j.procs.2020.05.143

Richardson, C. (2020). Supporting collaborative creativity in education with The i5 Framework. Educational Action Research. https://doi.org/10.1080/09650792.2020.1810731

Sampurno, M. B. T. (2018). Learning through children's paintings. Proceeding of 2 nd International Conference of Arts Language And Culture, 405-413.

Sampurno, M. B. T., Kusumandyoko, T. C., \& Islam, M. A. (2020). Budaya Media Sosial, Edukasi Masyarakat, dan Pandemi COVID-19. SALAM: Jurnal Sosial Dan Budaya SyarI, 7(5). https://doi.org/https://doi.org/10.15408/sjsbs.v7i5.15210

Simatupang, L. (2013). Pergelaran: sebuah mozaik penelitian seni-budaya. Jalasutra.

Strycker, J. (2020). K-12 art teacher technology use and preparation. Heliyon, 6(7). https://doi.org/10.1016/j.heliyon.2020.e04358

Szymański, M. (2019). Computer Games in Art History. Traditional architecture and painting presented in virtual reality. E-Methodology, 5(5), 84-99. https://doi.org/10.15503/emet.v5i5.449

Versteijlen, M., Perez Salgado, F., Janssen Groesbeek, M., \& Counotte, A. (2017). Pros and cons of online education as a measure to reduce carbon emissions in higher education in the Netherlands. Current Opinion in Environmental Sustainability, 28, 80-89. https://doi.org/10.1016/j.cosust.2017.09.004

Yazdani, S., \& Shahbazi, M. (2017). The Role Played by Art in the Education and Creativity of the Iranian Students. International Journal of Educational Sciences, 19(1), 1-5. https://doi.org/10.1080/09751122.2017.1368154 